\title{
El cortometraje latinoamericano moderno. Experimentación estética y vínculos con el campo cultural en Argentina, Cuba y México
}

\section{The Modern Latin American Short Film. Aesthetic Experimentation and Connections with the Cultural Field in Argentina, Cuba and Mexico}

Artículo recibido el 24 de julio de 20I7; devuelto para revisión el 4 de diciembre de 20I7; aceptado el 23 de abril de 20I8, https//doi/IO.2220I/iie.18703062e.20I8.II3.2654

Javier Cossalter Universidad de Buenos Aires-Consejo Nacional de Investigaciones Científicas y Tecnológicas, Argentina. javiercossalter@gmail.com

Publicaciones más relevantes

Resumen

Palabras clave
Editor del "Dossier el cortometraje documental latinoamericano en los años sesenta y setenta", Imagofagia, núm. I2 (2015); "Renovación estética e instrumentalización política radical. El cortometraje moderno en Argentina (1955-1976)", Questión. Revista Especializada en Periodismo y Comunicación I, núm. 47 (2015): 309-324; "Política y transformación en el cortometraje documental argentino (1966-1976)", Perspectivas de la Comunicación 8, núm. I (20I5): 79-IOO; "El cine experimental de cortometraje en la Argentina de los años sesenta y setenta: apropiaciones y vinculaciones transnacionales", ERAS - European Review of Artistic Studies 5, núm. 4 (2014): 32-49; "El testimonio en el cortometraje documental argentino de los años sesenta y setenta. Identidades marginadas y nuevas voces", Cine Documental, núm. Iо (2014): 45-70.

Las cinematografías de Argentina, México y Cuba, heterogéneas en su conformación fílmica industrial, advirtieron a mediados de la década de los años cincuenta una renovación productiva y expresiva en diálogo con las transformaciones acontecidas en el terreno cultural. Fue precisamente el cortometraje aquel medio impulsor de la renovación. El presente artículo realiza un análisis comparado de dichos cines a partir de tres textos fílmicos de corta duración y de los respectivos contextos cinematográficos y culturales de producción. Al explorar la corriente del filme sobre arte, el cortometraje evidencia su papel fundamental en la constitución de la modernidad cinematográfica latinoamericana mediante la experimentación estética del lenguaje y de su vínculo semántico con la reconfiguración acaecida en el campo cultural y artístico regional.

Cortometraje; modernidad cinematográfica; renovación estética; arte; reconfiguración cultural. 
Abstract The cinematography of Argentina, Mexico and Cuba - heterogeneous in their industrial filmmaking — saw a productive and expressive renewal in the mid-I950s in dialogue with other transformations in the cultural field. The driving force of renovation was the short film. The present article makes a comparative analysis of these cinemas and the respective cinematographic and cultural contexts of production as exemplified in three short films. Exploring the genre of films dealing with art, this article shows the fundamental role of the short movie in the constitution of modern Latin American cinema through the aesthetic experimentation with language and its semantic link with the reconfiguration of regional cultural and artistic fields.

Keywords Short film; modern cinema; aesthetic renovation; arts; cultural reconfiguration. 


\author{
JAVIER COSSALTER \\ UNIVERSIDAD DE BUENOS AIRES-CONSEJO NACIONAL DE \\ INVESTIGACIONES CIENTÍFICAS Y TECNOLÓGICAS \\ ARGENTINA
}

\title{
El cortometraje latinoamericano moderno \\ Experimentación estética y vinculos con el campo cultural en Argentina, Cuba y México
}

\section{Introducción}

$\mathrm{H}$ acia mediados de los ańos cincuenta comenzó a gestarse el cine moderno en Latinoamérica, el cual alcanzó en la década siguiente su pleno desarrollo. El surgimiento de este fenómeno en la región se produjo, en términos generales, gracias a una reconfiguración del ámbito cinematográfico y una transformación del campo cultural y artístico. En la década de los cincuenta comenzó a vislumbrarse un agotamiento del modelo clásico-industrial. $\mathrm{Al}$ mismo tiempo nacieron y proliferaron nuevos focos de producción, algunos de sustento independiente, otros de respaldo estatal. Estas variables estimularon una renovación de las estructuras productivas y expresivas dentro del séptimo arte. Ahora bien, esta experiencia no se llevó a cabo de forma homogénea, puesto que mientras ciertos países efectivamente habían consolidado una industria cinematográfica fuerte, otros apenas ofrecían una producción intermitente. A su vez, algunas iniciativas innovadoras contaban con apoyo estatal y otras se organizaban de manera alternativa y artesanal. No obstante, sí existió un componente común y aglutinador en este proceso: la presencia activa del cortometraje. 
En este sentido, determinar cuál fue el papel que asumió el filme breve en este periodo es la interrogante que motiva la presente investigación. Para ello, planteo la siguiente hipótesis: el cortometraje cumplió una función central en el asentamiento de la modernidad cinematográfica en América Latina mediante una renovación expresivo-semántica y por medio del vínculo fluido con el campo cultural local y regional. Una variante particular que aunó estas cualidades fue la del filme sobre arte. En ella puede observarse una marcada experimentación estética del lenguaje fílmico, así como una conexión directa con los movimientos artísticos de ruptura, la historia del arte nacional y las mutaciones del campo cultural local y global en la etapa señalada.

Entonces, el propósito de este artículo consiste en analizar de forma comparada dicha tendencia desarrollada en el corto en Argentina, Cuba y México a partir de ciertos ejemplos representativos y sus respectivos contextos de producción ${ }^{\mathrm{I}}$ con el interés de examinar tres patrones comunes del filme breve en el curso de la modernidad en tres cinematografías disímiles: la explicitación de los recursos que brinda el dispositivo fílmico, la hibridación de categorías fílmicas o modelos cinematográficos ${ }^{2}$ y las novedades semánticas en diálogo con el campo cultural y artístico. La pertinencia de esta empresa reside en la singularidad del objeto de estudio en su articulación con el enfoque de aproximación. Por un lado, la productividad del corto en la modernidad cinematográfica no ha sido una problemática estudiada de forma minuciosa en la historiografía del cine. Por el otro, y en combinación con lo anterior, la metodología del análisis comparado entre cinematografías latinoamericanas le agrega un plus de originalidad. El trabajo se inscribe en lo que Ana Laura Lusnich denomina como segundo momento de los estudios comparados sobre cine en América Latina, sustentado en la definición de un sistema de relevancia y el establecimiento de rangos de contraste específicos que serán explorados de modo transversal en los diversos cines contemplados. ${ }^{3}$

I. Los cortos seleccionados son: Spilimbergo (Jorge Macario, 1959), de Argentina; El retrato (Óscar Valdés y Humberto Solás, 1963), de Cuba, https://www.youtube.com/watch?v=FVDjn6E4qvl; y La creación artística: Vicente Rojo (Juan José Gurrola, I965), de México, https://www.filmoteca. unam.mx/cinelinea/videos/video4o.html.

2. Nos referimos aquí al entrecruzamiento y la disolución de los límites entre la ficción, el documental y el cine experimental.

3. Ana Laura Lusnich, "Pasado y presente de los estudios comparados sobre cine latinoamericano", Comunicación y Medios, núm. 24 (20II): 25-42, consultado el I3 de marzo de 20I7, en https://comunicaciónymedios.uchile.cl/index.php/RCM/article/view/19892 
En pos de llevar adelante este trabajo se destinará una primera sección a esbozar el panorama del cine latinoamericano en la transición del periodo clásico al moderno, diferenciando los cines con tradición industrial de aquellos que evidenciaron una producción inestable, haciendo especial énfasis en las tres cinematografías seleccionadas. Asimismo se puntualizarán los caracteres del cortometraje que justifican su injerencia y eficacia en la renovación de cines heterogéneos y dispares. El segundo apartado estará enfocado en el contexto cultural de los países escogidos con el afán de observar la creación de instituciones y movimientos artísticos novedosos y rupturistas, y plantear la trama renovadora en el terreno cinematográfico. A su vez se indagará de forma general en la corriente del filme sobre arte en Argentina, Cuba y México, mencionando algunos títulos y señalando sus características principales. Finalmente en el último punto se procederá a realizar el análisis textual comparado de los tres exponentes elegidos de esta tendencia en cada país, con el objetivo de constatar la presencia de rasgos renovadores comunes y confirmar la vinculación del corto con el paisaje cultural y artístico. Ahí se recuperarán las cualidades potenciales del filme breve y se emplearán conceptos tales como "cine-ensayo", "cineplástica", "motivos visuales", "encuadre" y "desencuadre" en tanto herramientas que posibilitarán analizar la estructura de los cortos y poner en relación al cine con las artes plásticas.

\section{El corto latinoamericano en el pasaje del cine clásico al moderno}

Para mediados de la década de los cincuenta pocas cinematografías latinoamericanas habían logrado constituir una tradición industrial estable, voluminosa y redituable. Argentina y México encabezaron y dominaron esta faceta en las décadas de los treinta y los cuarenta, mientras que en Brasil la consolidación del modelo industrial se produjo en los años cincuenta. Cuba y Chile, por ejemplo, atravesaron "modestas experiencias industrializantes" por aquellos años. 4 Venezuela, Perú y Colombia también compartieron la experiencia de una producción intermitente, con vaivenes productivos heterogéneos. En una última

4. Paulo Antonio Paranaguá, Tradición y modernidad en el cine de América Latina (Madrid: Fondo de Cultura Económica, 2003), IO2. 
línea se ubican países como Bolivia, Ecuador, Uruguay, Paraguay y el conglomerado centroamericano, caracterizados por "una cinematografía vegetativa". 5

Los tres cines escogidos para este trabajo presentan similitudes y diferencias en torno a la configuración originaria de su estructura fílmica industrial. Como bien mencioné, Argentina y México fueron pioneras en el establecimiento de dicha tradición al conformar sus respectivos modelos a imagen y semejanza de Hollywood, mediante un sistema propio de estudios, estrellas y géneros que alimentaba el rédito económico. En el plano estético los grandes decorados, el tinte melodramático, la ubicuidad de la mirada y una puesta en escena transparente caracterizaron en gran medida las producciones de la época. ${ }^{6} \mathrm{Si}$ bien las dos naciones lideraron la producción cinematográfica latinoamericana en los ańos treinta y cuarenta, México comenzó a sacar provecho luego de su pronunciamiento a favor de los aliados en la segunda guerra mundial gracias al abastecimiento de película virgen por parte de los Estados Unidos de América. No obstante, ambas advirtieron cierto desgaste del modelo industrial a mediados de los años cincuenta. El caso de Cuba es distinto. Hasta la revolución de 1959 los intentos por establecer una industria del cine fracasaron. Por ejemplo, PECUSA produjo seis largos entre 1938 y I940, producciones CHIC realizó un puñado de obras y Cuba Sono Films encaró una serie de documentales-testimonio y algunos cortos de ficción. ${ }^{7}$

En los años cincuenta y a lo largo de la década siguiente se produjo (en gran parte de la región) una reorganización del campo cinematográfico con la creación de nuevos centros de formación, producción y reflexión (talleres,

5. Paranaguá, Tradición y modernidad, 24.

6. En Argentina, Lumitón y Argentina Sono Film fueron los dos primeros estudios que se afianzaron en el terreno industrial. Sus películas inaugurales presentaban a personajes emblemáticos que se consagrarían en el estrellato local: Libertad Lamarque, Tita Merello, Luis Sandrini, Pepe Arias, entre otros. El melodrama tanguero fue uno de los géneros pioneros y más exitosos de la producción nacional. Por el lado de México, compañías productoras como Filmex y Films Mundiales fueron algunas de las más influyentes. El melodrama también fue un género de peso junto con la denominada comedia ranchera. Estrellas como María Félix, Jorge Negrete, Dolores del Río, Tito Guízar y Pedro Armendáriz tuvieron un amplio reconocimiento tanto en el mercado local como en el plano internacional. En pos de acercarse de forma general al cine del periodo clásico en Argentina y México, véase Claudio España, comp., Cine argentino. Industria y clasicismo 1933/1956, vol. I (Buenos Aires: Fondo Nacional de las Artes, 2000); y Emilio García Riera, Historia del cine mexicano (Ciudad de México: Secretaría de Educación Pública, 1986), respectivamente.

7. Para profundizar en el estudio de esta etapa del cine cubano, véase María Caridad Cumaná y Walfredo Piñera, Mirada al cine cubano (Bruselas: ocıc, 1999). 
seminarios, centros de experimentación, escuelas de cine y cineclubes), tanto en países con un sólido modelo industrial como en aquellos de producción esporádica. En Argentina se puede señalar el Taller de cine (I95I), el Seminario de Cine de Buenos Aires (1953), las escuelas dependientes de universidades nacionales hacia 1956 - La Plata, Córdoba, El Litoral. En México se destaca la formación del grupo Nuevo Cine a comienzos de los sesenta, el nacimiento de la Sección de Actividades Cinematográficas (1959) y del Centro Universitario de Estudios Cinematográficos (CUEC) (1963), dependientes de la Universidad Nacional Autónoma de México (UNAM). En Cuba se menciona al cineclub de la Universidad de La Habana y a la organización cultural Nuestro Tiempo, en los años cincuenta, aunque fue precisamente luego de la revolución con la creación del Instituto Cubano del Arte e Industria Cinematográficos (ICAIC) que la renovación dentro del séptimo arte tuvo un lugar preponderante.

$Y$ es justamente en este contexto en el que el cortometraje adquirió un papel capital como medio para manifestar los nuevos valores y desafíos de una joven generación de cineastas. Es decir, que la renovación expresiva y semántica de la modernidad estuvo impulsada por el filme de corta duración, trascendiendo entramados cinematográficos y culturales diversos. ${ }^{8}$ En este sentido, se entiende que las especificidades del cortometraje exceden el aspecto longitudinal de la película. Por tal motivo, se desestiman las nociones de formato y género para referirse a éste, y se opta por considerarlo en tanto medio de expresión audiovisual con particularidades que se erigen como potencialidades en términos económicos, estéticos y estructurales. Por un lado, esta menor duración sí determina menores costos y su gradual corrimiento hacia los márgenes de la industria le ha concedido mayor libertad estética debido a la ausencia de condicionamientos comerciales. En palabras de Paulo Pécora, "su brevedad, su marginalidad y el uso que a veces hace de recursos cinematográficos básicos, elementales, casi amateurs, son cosas que ayudan al cortometraje a ser lo que debería ser: un espacio de libertad inigualable". ${ }^{9}$ Libertad que se traduce en la búsqueda de lenguajes nuevos y en la posibilidad de abordar temáticas poco frecuentes. Por otro lado, el factor tiempo no funciona como una limitación; el corto no es un pequeño largo. Se produce entonces una adecuación de

8. Como bien se ha apuntado, el corto se hizo presente tanto en organizaciones independientes de autosustento, como en entidades estatales bajo la promoción de los propios organismos institucionalizados.

9. Paulo Pécora, "Algunas reflexiones sobre el cortometraje", en Hacer cine: Producción audiovisual en América Latina, comp. Eduardo Russo (Buenos Aires: Paidós, 2008), 383. 
la acción filmada a la duración. No todo lo que se sostiene coherentemente en una hora y media lo hace en unos pocos minutos, ni viceversa. Sí se podría decir que en el corto se condenan los tiempos. A su vez, tanto la banda de imagen como la de sonido conquistan mayor fuerza gracias a esta condición y concepción diferente de la temporalidad. El modo de articulación entre ambas puede volverse reflexivo y consciente, poniendo al descubierto la convención y el artificio. Muy a menudo la imagen cumple un papel fundamental y destacado, en cambio en otros casos la precisión de los diálogos y las voces, la utilización marcada del sonido y el "recurso ingenioso de la música" señalan el camino. ${ }^{\circ}$ También la estructura del cortometraje puede predisponer al receptor para que asuma una actitud atenta y una posición activa. Como bien expresan Mariangel Bergese, Isabel Pozzi y Mariana Ruiz, "el espectador del corto adopta una actitud diferente ante lo que ve, porque prevalece en él la idea de fugacidad que lo obliga a mantener una atención constante. Como receptor activo es el que completa los hechos". ${ }^{\text {.I }}$

Ahora bien, ciertos atributos señalados son potenciados en el vínculo con las diferentes categorías fílmicas. Por ejemplo, en el corto de ficción la condensación del tiempo puede reflejarse en una historia cuyo conflicto se desarrolla de forma temprana y la presentación de los personajes se lleva a cabo en la acción misma. En el cine documental la efectividad y la relación de inmediatez en el vínculo con el receptor cobran particular relevancia. La noción de efectividad en términos de Susana Velleggia (que apunta a las consecuencias extracinematográficas que se desprenden de la relación del cine con sus destinatarios) encuentra en el corto un vehículo eficaz para desarrollarse. ${ }^{\text {I2 }}$ En relación con el cine experimental la reflexión del medio, la puesta en relieve de los aspectos perceptuales, concepciones narrativas no tradicionales y la participación también activa del receptor son bien acogidas por las posibilidades estéticas y estructurales del filme breve.

Por lo dicho, se desprende la capacidad del cortometraje de orientarse como un dispositivo de experimentación del lenguaje y la materialidad cinematográfica, así como también se erige en tanto claro instrumento de acción, persuasión y transformación de la realidad. Por tal motivo, se puede afirmar que el

Io. Thierry Méranger, Le Court métrage (París: Cahiers du Cinéma, 2007), 78.

II. Mariangel Bergese, Isabel Pozzi y Mariana Ruiz, "Anatomía de cuerpos menudos. Sobre el pasado y el presente del cortometraje nacional”, Ossessione, núm. I (1997): 5.

I2. Susana Velleggia, Cine: Entre el espectáculo y la realidad (Ciudad de México: Claves Latinoamericanas, 1986). 
filme breve se convirtió en el eslabón principal de la renovación fílmica de los años cincuenta y sesenta, y en una pieza fundamental del cine político de finales de década. ${ }^{13}$ En esta oportunidad me concentraré plenamente en la labor del corto en la etapa de asentamiento de la modernidad cinematográfica a partir de la variante del filme sobre arte.

\section{Contexto cultural y artístico}

La renovación cinematográfica iniciada en Latinoamérica a partir de mediados de la década del cincuenta estuvo íntimamente enraizada en la modernización acaecida al interior del ámbito cultural y artístico de la región. No obstante, y como ya anticipé, cada nación experimentó desarrollos particulares, si bien se encontrarán algunos puntos en común.

En Cuba, la revolución de 1959 inició un nuevo proceso político y también cultural. ${ }^{14}$ Fue desde el Estado que se promovió un proyecto social, cultural y artístico sustentado en la revalorización de lo nacional, la democratización del acceso a la cultura y la alfabetización, entre otras banderas. Para ello, nuevas instituciones se pusieron en marcha. El Instituto Cubano del Arte e Industria Cinematográficos (ICAIC) fue la primera entidad cultural creada por el gobierno a través de la Ley de Cine (Ley 169) en marzo de 1959. En sintonía con el proyecto general del movimiento revolucionario, uno de los puntos de la ley que daba origen al Instituto afirmaba que "es el cine el más poderoso y sugestivo medio de expresión artística y de divulgación y el más directo y extendido vehículo de educación y popularización de las ideas". ${ }^{\text {Is }}$ En este sentido, los primeros años de la revolución estuvieron marcados por transformaciones profundas en el ámbito cinematográfico como la creación de un noticiario y una cinemateca,

I3. El cortometraje acompañó la politización que posteriormente abrazó el denominado Nuevo Cine Latinoamericano. El corto documental latinoamericano llevó adelante las banderas de la lucha contra el hambre, el subdesarrollo, el imperialismo y la dependencia, entre otras consignas destacadas. Véase Cossalter, "El cortometraje documental latinoamericano en los años sesenta y setenta", consultado el 20 de abril de 2017 , en www.asaeca.org/imagofagia/index.php/imagofagia/ issue/view/23

14. A comienzos de los ańos cincuenta pueden ya vislumbrarse algunos focos de renovación cultural como por ejemplo la organización "Nuestro Tiempo" que reunía a intelectuales y artistas de corte socialista.

I5. "Ley de creación del ICAIC", Gaceta Oficial, Primera Sección La Habana, 2 de marzo de 1959. 
la nacionalización de las salas de cine y de las empresas extranjeras de distribución, y la organización del Departamento de Divulgación Cinematográfica con el objetivo de llevar el cine a todos los rincones de la isla. En enero de 196r se fundó el Consejo Nacional de Cultura, organismo fundamental del programa cultural de la revolución, y en agosto, la Unión de Escritores y Artistas de Cuba (UNEAC) presidida por el poeta Nicolás Guillén. Ésta se constituyó como espacio nuclear de la intelectualidad cubana. ${ }^{16} \mathrm{Al}$ año siguiente se concibió la Escuela Nacional de Arte (ENA) con cuatro diferentes ramas: Ballet, Música, Arte Dramático y Artes Plásticas. La intención era ampliar a todos los sectores la enseñanza del arte. Finalmente, se señalan algunas de las innovaciones que resaltan en el terreno artístico. Con relación a las artes plásticas sobresalieron ciertas tendencias durante la primera década de la revolución cuyo común denominador fue la experimentación con el lenguaje. Se destaca el arte figurativo por medio del cartelismo, la nueva figuración, la abstracción, el expresionismo y el pop-art. Por el lado de la música la Nueva Trova, surgida en los años sesenta, combinaba la música popular con letras progresistas íntimamente ligadas a los ideales revolucionarios. Allí emergieron, entre otros, Silvio Rodríguez y Pablo Milanés.

Argentina experimentó a partir de mediados de los años cincuenta una modernización cultural y artística que se apoyó hacia finales de década en un programa económico desarrollista. ${ }^{17}$ Como bien expresan Ana Longoni y Mariano Mestman:

Desde la segunda mitad de la década del 50 y a lo largo de la década siguiente, se vive un clima de fuerte modernización en la sociedad argentina. Este proceso, que es parte de la renovación cultural del mundo occidental, implica a nivel local el surgimiento de nuevos impulsos, así como la visibilidad o la

I6. La misma se gestó en el Primer Congreso de Escritores y Artistas de Cuba celebrado poco tiempo después del famoso discurso de Fidel Castro denominado "Palabras a los intelectuales". Entre los objetivos de la organización figuraban: fomentar el diálogo entre los escritores y artistas, favorecer la formación, mantener relaciones con diversas instituciones culturales estatales e incentivar el intercambio con artistas de otros países.

17. De la mano del presidente Arturo Frondizi (1958-1962) se puso en marcha el modelo desarrollista que pretendía, principalmente, promoverr en el crecimiento de las industrias de base mediante la incorporación masiva de capital extranjero. Asimismo se listaba entre sus objetivos la modernización de la infraestructura de transporte y comunicaciones. Véase Marcelo Cavarozzi, Autoritarismo y democracia (Buenos Aires: Eudeba, 2002). 
potenciación de otros que hasta entonces se habían desarrollado en forma atomizada. ${ }^{18}$

En esta línea, se crearon instituciones privadas y estatales que participaron en la reconfiguración del mapa cultural local como por ejemplo la editorial Eudeba, el Consejo Nacional de Investigaciones Científicas y Tecnológicas (CONICET), ${ }^{19}$ el Fondo Nacional de las Artes (FNA) y el Instituto Di Tella. ${ }^{20}$ Me refiero aquí al accionar de estas dos últimas entidades puesto que han sido cruciales en cuanto al estímulo y la difusión de propuestas artísticas de vanguardia. El FNA se fundó en 1958 y funcionó como un ente autárquico estatal destinado a fomentar, mediante créditos y subsidios, actividades artísticas y literarias nacionales. Entre ellas figuraban las artes plásticas, el teatro, la música, las letras, la danza, la cinematografía (sobre la cual me detendré luego), y las expresiones folklóricas, entre otras. A su vez, acorde a sus metas iniciales, el Fondo invertiría dinero en infraestructura y financiaría tanto concursos como exposiciones relacionadas con el mundo del arte. Por otro lado, el mismo ańo se creaba el Instituto Di Tella conformado por tres pilares: el Centro de Artes Visuales (CAV), el Centro de Experimentación Audiovisual (CEA) y el Centro Latinoamericano de Altos Estudios Musicales (CLAEM). El propósito del Instituto residía en incentivar la creación estética y difundir las corrientes experimentales (locales y mundiales) en torno al campo visual, audiovisual y musical. Así, por ejemplo, en el terreno de las artes plásticas se realizaban muestras de artistas extranjeros que también

I8. Ana Longoni y Mariano Mestman, Del Di Tella a "Tucumán Arde". Vanguardia artística y política en el 68 argentino (Buenos Aires: Eudeba, 2008), $4 \mathrm{I}$.

19. Óscar Terán, coord., Ideas en el siglo. Intelectuales y cultura en el siglo XX latinoamericano (Buenos Aires: Siglo XXI Argentina/Fundación OsDE, 2004).

20. El campo académico e intelectual también se renovó gracias el ingreso de corrientes de pensamiento como el existencialismo, el estructuralismo y el marxismo; la creación de las carreras universitarias de Sociología, Psicología y Educación; y la aparición de un nuevo aparato crítico que legitimaba la producción artística y cultural novedosa. Del mismo modo, la literatura y el teatro evidenciaron aspectos innovadores. Por un lado, en los cincuenta apareció una generación de jóvenes pensadores denominada "los denuncialistas" que desde la crítica y mediante la libertad de las formas se proponían revisar el pasado en pesquisa de la literatura nacional. Por el otro, ya en los sesenta, el "realismo reflexivo" instalaba la subjetividad por medio del intercambio de relaciones personales entre los personajes (procedimiento conocido como "encuentro personal"), a diferencia del realismo objetivo del teatro de la década previa. Otros recursos novedosos fueron el relajamiento de la acción y los personajes en crisis. Véase Osvaldo Pellettieri, Una historia interrumpida (Buenos Aires: Galerna, 1997). 
participaban en la Bienal de Venecia y se otorgaban premios nacionales e internacionales. Las prácticas innovadoras en el ámbito local estaban principalmente orientadas al pop art (bajo la forma del environment) y al neofigurativismo (expresionismo figurativo rupturista). En el aspecto audiovisual predominaron durante los primeros años las exhibiciones itinerantes que combinaban cortometrajes sobre arte con proyecciones múltiples de tipo experimental. En el ala teatral, además del estreno de El desatino (1965) de Griselda Gambaro (principal exponente de la neovanguardia absurdista), circulaban los happening y las formas de creación colectiva. Finalmente, en relación a la música, el Centro ofrecía becas de estudio por un lado, la presencia de compositores extranjeros por el otro, y conciertos abocados a las corrientes musicales modernas experimentales, incluyendo obras de música electrónica.

Bajo la presidencia de Miguel Alemán (1946-1952), pero más precisamente durante los siguientes dos sexenios, ${ }^{21}$ México vivió en el plano económico un proceso desarrollista (conocido como desarrollo estabilizador) que según Carlos Monsiváis tuvo su contraparte en el debilitamiento del nacionalismo cultural. ${ }^{22}$ Sin embargo, según el escritor, el desarrollismo cultural recién se instalaría en los años sesenta. En palabras de Monsiváis: "En los sesentas, la cultura constituye una de las dos técnicas fundamentales para alcanzar y gozar la modernidad". ${ }^{23}$ No obstante, ya en los ańos cincuenta pueden observarse rasgos renovadores en el campo cultural como el surgimiento de los suplementos culturales en el periódico El Nacional, en Novedades y en la revista Siempre!' Luego, aparecieron nuevas editoriales como ERA y Siglo XXI, y se fundaron el Museo Nacional de Antropología y el Museo de Arte Moderno. A su vez sobresale el Seminario sobre Cine dictado por Jaime García Terrés dentro de la Universidad Nacional Autónoma de México en 1954, la labor de la Coordinación de Difusión Cultural de la unam y de Radio unam (entre 1953 y 1965), que colaboraba con la circulación del arte y la cultura emergente, y el fortalecimiento de la crítica, no sólo en el ámbito literario sino también en el terreno del cine. A principios de la década de los sesenta se constituyó el grupo Nuevo Cine, foco principal de la renovación cinematográfica mexicana, que incentivaría la

2I. Éstos se corresponden con las presidencias de Adolfo Ruiz Cortines (1952-I958) y Adolfo López Mateos (1958-1964).

22. Dicho sentimiento implicaba un rechazo de la tradición y un progresivo abandono de lo "mexicano" como eje rector.

23. Carlos Monsiváis, "Notas sobre la cultura mexicana en el siglo xx", en Historia general de México (Ciudad de México: Colmex, 1976), I492. 
concreción del I Concurso de Cine Experimental en I964 en el cual participarían varios nuevos directores. Por aquellos años se habían gestado también la Filmoteca de la unam y el Centro Universitario de Estudios Cinematográficos (CUEC), otros dos pilares de la nueva generación de cineastas. Ahora bien, es en el terreno de las artes plásticas donde surgió en los años cincuenta un claro enfrentamiento con el nacionalismo cultural sostenido por la Escuela Mexicana de Pintura y los organismos que la legitimaban. Fue la denominada Generación de la Ruptura, la cual se opuso enfáticamente al muralismo entendido como un arte caracterizado por el nacionalismo y basado en el mito y la revolución. Allí se involucraron artistas como Alberto Gironella, José Luis Cuevas, Vicente Rojo y Lilia Carillo, entre otros. La ruptura se llevó a cabo, al igual que en Cuba y en Argentina, mediante el neofigurativismo y la abstracción; proceso internacionalista que en México se había mantenido esquivo. Pero a diferencia de Cuba, donde el Estado promovía la renovación, allí se inició fuera de los canales oficiales. Como bien expresa Lelia Driben: "La ruptura nació en las galerías porque la Escuela Mexicana tenía cooptados los sitios públicos”. ${ }^{24}$ Estos sitios privados de consolidación fueron esencialmente dos: la Galería Juan Martín y la Galería Pecanins. Hacia mediados de los sesenta el Instituto Nacional de Bellas Artes abrió espacios donde convivirían, no sin fricciones, los nacionalistas conservadores y los modernistas rupturistas. En definitiva, y producto en parte del contacto intenso entre artistas de diversa índole, tanto en el campo del cine como en el de la literatura, la música y las artes plásticas "una nueva generación comienza a tomar su lugar y exige que lo nacionalista sea confrontado con nuevas corrientes del arte mundial". ${ }^{25}$

Dentro de este panorama de renovación artístico-cultural se encuentra, claro está, el cine. Algunas premisas ya han sido abordadas, puesto que las cinematografías nacionales se conformaron como bastiones de la modernización cultural. De acuerdo a lo comentado, tanto Argentina como México sufrieron una parálisis en la producción fílmica industrial a partir de mediados de los años cincuenta. Y en ambos países la renovación se gestó por fuera de dicha estructura, aunque sustentada en muchos casos desde organismos estatales. En Argentina, los jóvenes aspirantes a convertirse en cineastas tenían que, hasta

24. Lelia Driben, La Generación de la Ruptura y sus antecedentes (Ciudad de México: Fondo de Cultura Económica, 20I2), 3I.

25. Javier Ramírez y Marcela Itzel García, "Luis Buñuel, un cineasta universal en el cine mexicano", en Desafio a la estabilidad. Procesos artísticos en México 1952-1967, ed. Rita Eder (Ciudad de México: Universidad Nacional Autónoma de México/Turner, 20I4), I66. 
la década del cincuenta, involucrarse en los rubros técnicos de la industria. Con la gestación de los talleres y las escuelas de cine nacieron nuevas formas de apre(he)nder los postulados técnicos y expresivos del séptimo arte. En I95I Jorge Macario, Arsenio Reinaldo Pica, Roberto Raschella y Jorge Tabachnik crearon el Taller de Cine cuya labor de aprendizaje y realización se mantuvo activa hasta 1964. Allí el cortometraje fue precisamente aquella herramienta que les facilitó la formación y el ejercicio, y que al mismo tiempo les permitió expresarse cinematográficamente. En 1956 se creó el Departamento de Cinematografía de la Universidad Nacional de La Plata, comandado por Cándido Moneo Sanz. En los primeros tiempos estuvo abocado tanto al cine de ficción como al cine documental, con un perfil no comercial, y fue también el cortometraje aquel vehículo de experimentación, aprendizaje y expresión. Al año siguiente se abrió el Instituto de Cinematografía de la Universidad Nacional del Litoral fundado por Fernando Birri. El postulado central era el de realizar un cine realista, nacional, popular y crítico. En éste surgieron filmes breves emblemáticos como Tire dié (Fernando Birri, 1958), Los 40 cuartos (Juan Oliva, 1962) y Pescadores (Dolly Pussi, 1968), exponentes de un cine social y político moderno. Finalmente, se podría aseverar que la mayoría de los jóvenes de la llamada Generación del Sesenta (quienes renovaron las formas expresivas y semánticas del largometraje de ficción argentino) se habían formado y nutrido en el ámbito del corto y de los cineclubes, así como circulaban por los pasillos de las escuelas de cine. En México, el estancamiento no sólo afectaba la calidad de las producciones sino que también influía en los aparatos de distribución y exhibición. Sin embargo, fue recién en 1964 que el Sindicato de Trabajadores de la Producción Cinematográfica (STPC) convocó al Concurso de Cine Experimental anteriormente aludido y a una segunda versión al año siguiente, en pos de promover un cine de mayor calidad. Asimismo, en 1966 se realizó el Segundo Concurso Internacional de Cortometraje de Guadalajara. Ahora bien, así como sucedió en Argentina, en México también surgieron nuevos focos de formación ajenos a la industria. En 1963 se fundó el Centro Universitario de Estudios Cinematográficos (CUEC) en el seno de la Universidad Nacional Autónoma de México. Ese mismo año el Centro inició una cuantiosa producción de cortometrajes cuyo puntapié inicial fue $A$ la salida (Giancarlo Zagni, I963). Cineastas luego reconocidos por su labor en el largometraje moderno mexicano egresaron del cuEc e incluso formaron parte del equipo docente. ${ }^{26}$

26. Entre ellos figuran Jaime Humberto Hermosillo, Alfredo Joskowicz y Leobardo López Arretche. 
Como bien señala Israel Rodríguez, "una característica esencial del cine universitario fue la liberación de la figura del director, ajeno por completo a las presiones del cine industrial" ${ }^{27} \mathrm{La}$ renovación continuó en los años posteriores con la creación de los grupos Cine 70 y Cine Independiente, y del Centro de Producción de Cortometrajes (CPC). Finalmente, el caso de Cuba es diferente. Como bien señalamos, es con la revolución de 1959 que se renovó la cinematografía, proceso impulsado por una estructura estatal, oficial e industrial: el ICAIC. Desde sus comienzos, el cine se consideró como un "instrumento de opinión y formación de conciencia" capaz de contribuir con "el espíritu revolucionario", aunque al mismo tiempo se afirma que "el cine debe conservar su condición de arte".$^{28}$ Entonces, si bien en los primeros diez años de vida se registran alrededor de ochenta cortos didácticos, más de noventa notas de Enciclopedia Popular y más de doscientos documentales (ligados en su mayor parte a difundir el accionar de la revolución en sus distintas facetas) ${ }^{29}$ también es posible encontrar filmes documentales, experimentales, de ficción y de animación que trascienden los confines estrictamente propagandísticos y que reflejan la cultura cubana a partir de la reflexión e innovación del lenguaje cinematográfico. El caso paradigmático es el de Santiago Álvarez cuyas obras, inmersas en el espíritu revolucionario, renovaron las formas expresivas mediante el uso del collage, el montaje en contrapunto y el movimiento autónomo de la cámara, entre otros recursos.

Como parte de este fenómeno cultural y artístico modernizador se sitúa la corriente fílmica sobre arte, predominantemente (pero no de forma excluyente) en la medida de corta duración. No obstante, este género particular no nació en Latinoamérica en el periodo abordado, aunque sí se podría afirmar que la experimentación estética se hizo sostenida en esta fase, y el vínculo práctico y semántico con el campo cultural se volvió aún más directo, dinámico y productivo. Ya en los años treinta surgieron algunas obras fílmicas emblemáticas en torno al arte como Velázquez (Ramón Barreiro, 1937) o Relato de un fresco (Luciano Emmer y Enrico Gras, 1968) en las cuales se realizaba una aproximación a las pinturas por medio de procedimientos eminentemente

27. Israel Rodríguez, "Un cine de autor para México", en Desafío a la estabilidad. Procesos artísticos en México 1952-1967, ed. Rita Eder (Ciudad de México: Universidad Nacional Autónoma de México/Turner, 2014), I40.

28. "Ley de creación del ICAIC", Gaceta Oficial, Primera Sección La Habana, 2 de marzo de 1959.

29. Datos extraídos de Juan Antonio García Borrero, Cine cubano de los sesenta: mito y realidad (Madrid: Libros de Ultramar, 2007), I62. 
cinematográficos: reencuadres, fundidos, montaje, dramatizaciones..$^{30}$ Fue, sin embargo, después de la segunda guerra mundial cuando esta tendencia se consolidó, puesto que la UNESCO consideró el filme sobre arte como una herramienta de cohesión cultural. En palabras de Guillermo G. Peydró, "el filme sobre arte se convierte entonces en el catalizador de un proyecto internacional de reconstrucción de los lazos europeos a través de la cultura”. ${ }^{3 \mathrm{I}}$ En 1948 se celebró la Primera Conferencia Internacional de Films sobre Arte y como consecuencia de ésta se fundó la Federación Internacional del Film sobre Arte (FIFA). A partir de entonces proliferaron las jornadas, las publicaciones y los catálogos en torno a la función social de dichos filmes.

Ahora bien, ¿en qué consiste el filme sobre arte? En un sentido amplio involucra a todo filme cuyo contenido esté relacionado con el mundo heterogéneo y múltiple de las artes. En una acepción más específica concuerdo con G. Peydró cuya conceptualización del filme sobre arte engloba solamente a las obras en las cuales se reflexiona acerca del arte aludido y en las que se produce una articulación de lenguajes entre el cine y dicho arte. Esta segunda línea cuadra a la perfección con mi objeto de estudio, ya que el mismo conjuga la experimentación del lenguaje fílmico (explotada por los rasgos potenciales del cortometraje) con la vinculación reflexiva en torno al campo cultural y artístico modernizador. Sin embargo, algunos filmes breves se hallarían más cerca de la distinción general, especialmente en Cuba donde el cine respondía muchas veces a un propósito descriptivo-pedagógico (aunque, de manera paradójica, este semblante no implicaba necesariamente una ausencia de reflexividad).

En Argentina el fortalecimiento del filme sobre arte llegó de la mano del Fondo Nacional de las Artes, organismo estatal creado en el contexto de modernización del campo cultural local. En junio de 1962, por medio de la resolución núm. 1635/62, se estableció un Régimen de Fomento al Cine de Cortometraje en donde se estipulaba la necesidad de fomentar producciones de corta duración que funcionaran como promotores "del patrimonio artístico y literario

30. Guillermo G. Peydró, "Filmar el arte, de París al D.F.", en Cineplástica. El film sobre arte en México 1960-1975 (Ciudad de México: Museo de Arte Moderno, 2015).

3I. Guillermo G. Peydró, "Del racconto al ensayo: cartografías del cine sobre arte”, tesis doctoral (Madrid: Universidad Autónoma de Madrid, 2014), 55. Para profundizar sobre la historia del género del filme sobre arte en el mundo véase este texto, que consiste en un estudio minucioso y metódico cuyas categorizaciones teóricas serán de valiosa utilidad para el último apartado de análisis textual. 
nacional en sus aspectos más amplios" ${ }^{32}$ El Fondo brindaba entonces préstamos de hasta la totalidad del presupuesto del filme a cortos que documentaran técnicas artísticas, expusieran la obra de artistas plásticos, compositores, intérpretes teatrales y de danza, entre otras actividades culturales. En 1969 se puso nuevamente en vigencia este convenio. Gran parte de los cortometrajes financiados fueron de índole documental, aunque no faltaron aquellos que justamente experimentaban con los lindes entre las categorías fílmicas de ficción y del propio cine experimental más genuino. ${ }^{33}$ Asimismo, la consolidación de dicha corriente por parte del FNA no estuvo únicamente centrada en el ámbito de la producción sino también en el plano de la difusión y visibilización. Además de conceder premios y enviar obras al exterior para su exhibición, en I964 el FNA organizó el Primer Festival Argentino del Film de Arte, evento que se reeditaría con éxito en 1965, 1967, 1971 y 1973. En cuanto a las obras fílmicas subsidiadas, por ejemplo, El bombero está triste y llora (Pablo Szir y Elida Stantic, 1965) trabaja la experiencia del arte plástico y los nińos mediante una estructura narrativa experimental con la inclusión de personajes performáticos; Guernica (Alfredo Mina, 197I) articula un acercamiento experimental a la pintura homónima junto con insertos documentales; El nacimiento de un libro (Mario Sábato, 1963) traduce de forma audiovisual pasajes de la novela Sobre héroes y tumbas (196I) de Ernesto Sábato; Buenos Aires en camiseta (Martín Schor, 1963) presenta un collage de dibujos articulados por medio del montaje y una voz en over, en torno a las costumbres de Buenos Aires. ${ }^{34}$

México no tuvo una entidad específica que promoviera filmes sobre arte. Sin embargo, a mediados de los sesenta esta tendencia se expandió, paralelamente a la renovación generalizada dentro del campo cinematográfico, en principio alrededor de la ya mencionada Generación de la Ruptura ligada a las artes plásticas. En esta línea se ubica Tamayo (Manuel González Casanova, 1967), corto centrado

32. "Fomento del Cine de Corto-Metraje", Documento del Fondo Nacional de las Artes, 7 de junio de 1962.

33. Para acercarse de forma general a un corpus de cortos documentales sobre arte financiados por el FNA, véase Javier Campo, "De óleo, tinta y celuloide. Cortometrajes sobre las artes en los sesenta y setenta", en Cine documental argentino. Entre el arte, la cultura y la política (Buenos Aires: Imago Mundi, 20I2).

34. La producción del FNA fue vasta y variada. El listado de cortos sobre artes plásticas incluye a Cuatro pintores hoy (Fernando Arce, 1964), Carta de Fader (Alfredo Mathé, 1965), Mundo nuevo (Simón Feldman, I965), Cándido López (Jorge Abad, I966); y en cuanto a la música se destacan Filiberto (1965) y Fuelle querido (1966), de Mauricio Berú, entre otros. 
en el proceso creador del artista y su obra, y a la trilogía de Juan José Gurrola La creación artística (1965), sobre José Luis Cuevas, Alberto Gironella y Vicente Rojo; serie que marca un claro enfoque político de la UNAM al conceder un espacio considerable a los artistas de la ruptura. Allí el cineasta utiliza al máximo el potencial del lenguaje cinematográfico recurriendo a las posibilidades del montaje y el encuadre, así como aplicando técnicas de intervención directa sobre el material sensible. Un ejemplo de esta corriente, fuera de la órbita de la mencionada generación de artistas plásticos, es José Guadalupe Posada (Manuel González Casanova, 1966), montaje audiovisual narrativo sobre grabados y caricaturas del artista homónimo. Felipe Cazals, quien luego formaría parte del grupo Cine Independiente de México, fue otro joven cineasta modernizador que realizó cortometrajes sobre arte, entre los que destacan: ;Qué se callen!; Leonora Carrington, el sortilegio irónico; Alfonso Reyes (1965) y Cartas de Mariana Alcoforado (1966). Asimismo se realizaron cortometrajes más tradicionales y descriptivos como Arte barroco (Juan Guerrero y Carlos González Morantes, 1968). Finalmente, sobresale también la conjunción del arte y la política, como por ejemplo Mural efimero (Raúl Kamffer, 1968), cortometraje documental en alusión al movimiento estudiantil de 1968 que registra el proceso creativo del mural junto con una voz en over poética y una música de rock en sintonía con el espíritu de época.

En Cuba el panorama se acerca más al reseñado en Argentina aunque fue desde la máxima institución cinematográfica oficial, el ICAIC, que se promovió una corriente de arte y cultura en su sentido amplio y heterogéneo, siguiendo los lineamientos generales de la revolución y poniendo el acento en la valorización de lo nacional. Uno de los puntos expuestos en la Ley de Creación del ICAIC decía que: "Nuestro país y cultura poseen características vocacionales perfectamente definidas, tipos, fórmulas expresivas, música, danza [...] de gran atracción y cuyo impacto y popularidad constituyen un hecho probado a través del interés y afición de los públicos de todas las latitudes". ${ }^{35}$ El objetivo del cine era entonces el de retratar, representar y difundir en imágenes dichos componentes de la vida y cultura cubana. Sin embargo es posible hallar también algunos exponentes que conjugaban la experimentación del lenguaje y la reflexión en torno al arte, y no una mera descripción revalorizadora de la práctica artística local. Éste es el caso de Cosmorama (Enrique Pineda Barnet, I964), filme netamente experimental fundado en un juego de luces y colores y una música concreta que toma como base el poema del pintor Sandú Darie; o Minerva

35. "Ley de creación del ICAIC", Gaceta Oficial, primera sección La Habana, 2 de marzo de 1959. 
traduce al mar (Óscar Valdés y Humberto Solás, 1962), otro corto experimental en donde dos bailarines danzan cerca del mar mientras se oyen versos de José Lezama Lima. Asimismo, se puede incluir aquí el corto de Ramón F. Suárez, Grabados revolucionarios (1963), un documental sobre la intervención de Estados Unidos a partir del contrapunto entre imágenes de archivo y grabados de dos pintores cubanos; si bien aquí la función social se impone. Dentro de una delimitación más abarcativa acerca del filme sobre arte puntualizo algunas obras como Combo universitario (Juan Carlos Tabío, 1963), en torno a un conjunto musical de estudiantes universitarios; Escuela de arte (Bernabé Hernández, 1965), sobre la Escuela de Ballet de las Escuelas Nacionales de Arte de Cubanacán; Portocarrero (Eduardo Manet, 1963), documental que describe la trayectoria artística del pintor cubano René Portocarrero e Historia de un ballet (suite yoruba) (José Massip, I962), que entremezcla los ensayos y la representación de una obra puesta en marcha por el Teatro Nacional, entre otras. ${ }^{36}$

En definitiva, es la conjunción de las diferentes aristas abordadas en torno a este fenómeno (el cortometraje como medio de expresión, la corriente del filme sobre arte, la experimentación estética del lenguaje y la renovación del campo cultural y artístico) lo que constituye la singularidad de este objeto de estudio caracterizado por un espíritu modernizador, y cuyos rasgos textuales analizaré a continuación.

\section{Análisis textual}

Antes de adentrarme en el análisis de los cortometrajes escogidos resulta pertinente esbozar el marco teórico a partir del cual abordaré el estudio comparado. Éste se utilizará en tanto soporte de los rangos de contraste planteados para la comparación: la hibridación de las categorías fílmicas, la experimentación con los procedimientos ofrecidos por el dispositivo cinematográfico y las innovaciones semánticas en el vínculo con el campo cultural y artístico. Dicho entramado incluye categorizaciones dentro de la corriente del filme sobre arte, nociones relativas a la estructura y el lenguaje fílmico, y herramientas de articulación entre el cine y la pintura, puesto que el corpus de cortos seleccionado refiere a las artes plásticas.

36. Las referencias de las obras aquí consignadas se tomaron de García Borrero, Cine cubano de los sesenta: mito y realidad. 
En principio tomo la taxonomía formulada por Guillermo G. Peydró para examinar la corriente del filme sobre arte. ${ }^{37} \mathrm{El}$ autor propone seis categorías. La primera se rotula "Dramatización de la pintura". Allí se agrupan los filmes donde el "marco" de la pintura se funde con el "cuadro" en su acepción fílmica. La pintura, gracias al montaje, se fragmenta y se narrativiza con la incorporación de la temporalidad que aportan, según mi entender, la cámara y el encuadre. A su vez, se construyen articulaciones entre diferentes representaciones y relaciones entre figuras y personajes. Ahora bien, no coincido con Peydró al caracterizar esta línea con el concepto de "montaje invisible" del cine clásico, ya que en muchos ejemplos es evidente el movimiento autónomo de la cámara. La segunda categoría es la "Tendencia poética" en la cual se utilizan al máximo las posibilidades del lenguaje cinematográfico. Como expresa el autor: "es una obra que tiene su apoyo metodológico en la poesía, en la sugerencia sensorial y conceptual, en el juego de asociaciones visuales".$^{38}$ La tercera se corresponde con el "Documental divulgativo". Es la opción más conservadora donde se recorre la obra sin poner al descubierto el artificio cinematográfico. Se trata de un "análisis formal pedagógico" ${ }^{39}$ Ahí sí se podría afirmar que se intenta borrar las huellas del dispositivo. En cuarto lugar se ubica el análisis crítico de la obra por medio del cine, y en quinto el denominado "Cine procesual" que consiste en la filmación del proceso creativo del artista. En última instancia aparece el "Cine de ficción" orientado generalmente a la vida del artista, en donde la puesta en escena juega un papel preponderante.

Al descartar las alternativas tres y cuatro, de estilo clásico, mi corpus se mueve entre las otras tipologías, aunque no necesariamente cada ejemplo debe adscribir de manera exclusiva a una categoría. Es en este punto donde entra en juego otra noción de Peydró para abordar estos filmes, que vincula y corrompe los límites entre las categorías anteriores: la idea del cine-ensayo. Según éste, el filme-ensayo se centra en la "interrogación sobre cada una de las variables de la obra fílmica”, ${ }^{\circ}$ y acude asimismo a la puesta en escena y a configuraciones narrativas específicas. Al ampliar las cualidades del mismo se puede decir que en el campo audiovisual el ensayo suele partir de la categoría documental (sobrepasando la tensión entre los polos de la veracidad y el punto de vista)

37. Peydró, Del racconto al ensayo.

38. Peydró, Del racconto al ensayo, 26.

39. Peydró, Del racconto al ensayo, 26.

40. Peydró, Del racconto al ensayo, 30. 
aunque para trascender sus confines. Según Arlindo Machado, "el filme-ensayo supera largamente los límites del documental. Incluso puede usar escenas de ficción, tomadas en estudio con actores, porque su verdad no depende de ningún 'registro' inmaculado de lo real, sino de un proceso de búsqueda e indagación conceptual". ${ }^{4 \mathrm{I}}$ Dos elementos son esenciales en este acercamiento: el montaje como principio constructivo y la estrategia discursiva personal y subjetiva. En definitiva, se trata de una forma cinematográfica autorreflexiva, afín a la modernidad, que pone en discusión las etiquetas tradicionales.

Y es justamente esta idea de ruptura con las nomenclaturas habituales aquello que subyace en la premisa de la hibridación de categorías fílmicas, que se vincula con la mutabilidad del filme-ensayo y que se erige como una cualidad exacerbada de la modernidad cinematográfica. En un repaso general sobre las conceptualizaciones de la ficción, el documental y el cine experimental se encuentran rasgos característicos de cada categoría fílmica, aunque también préstamos entre éstas que no ponen en discusión el estatuto de las mismas. Por ejemplo, una estructura dramática en el documental; veracidad en cuanto a su aproximación con lo real en la ficción; manipulación de la realidad o acercamiento a la narración en el cine experimental. ${ }^{42}$ No obstante, lo interesante surge cuando hay una propuesta intencional por borrar y confundir las fronteras entre los modelos cinematográficos, ya sea tomando elementos de uno para poner en escena temas, expresiones y objetivos característicos de otro, o mediante la efectiva hibridación de los mismos donde resulta imposible determinar cuál predomina. Es decir que el entrecruzamiento de las categorías se posiciona como un estatus estructural del filme. Finalmente, esta profunda subjetivación del enfoque, presente en el cine-ensayo, y el debilitamiento de las fronteras entre las categorías fílmicas descubren en el cortometraje un espacio propicio para su desarrollo. La ausencia de condicionamientos comerciales deriva en la libertad para seleccionar los temas, los problemas y las formas expresivas. A su vez, la potencialidad estructural del corto en cuanto a duración, concentración e intensidad favorece y permite sostener de modo eficaz ciertas prácticas cercanas al collage. En este sentido, el reparo consciente

4I. Arlindo Machado, "El filme-ensayo", La Fuga (invierno, 20I0): 23, consultado el I2 de abril de 20I7, en www.lafuga.cl/el-filme-ensayo/409

42. Para acercarse a una descripción de las categorías fílmicas y sus relaciones, véase Vicente José Benet, "Otros modelos cinematográficos: cine documental, experimental y de animación", en Un siglo en sombras. Introducción a la historia y la estética del cine (Valencia: Ediciones de la Mirada, 1999). 
sobre el dispositivo y la construcción de un relato o entramado de imágenes y sonidos que escapa de las formas convencionales motiva la puesta en relieve de la autorreflexión del medio expresivo.

Por otro lado, recurro a ciertos conceptos que establecen vinculaciones entre el cine y las artes plásticas, y que me facilitan al mismo tiempo detenerme en rasgos comunes del cine en el ámbito regional. Éste es el caso de la noción de "motivos visuales" teorizada por Jordi Balló, la cual consiste en momentos aislables en el filme, "segmentos de significación con duración temporal explícita", 43 que se puedan reconocer y distinguir en diferentes películas. El carácter estético del motivo visual es aquello que lo comunica directamente con la tradición pictórica. Ahora bien, más interesante resulta la conceptualización que a partir de ello realiza Ana Laura Lusnich cuando propone la idea de "motivos emergentes, propios de cada época o contexto cinematográfico". 44 De este modo, determinados motivos observados en el corpus seleccionado podrían responder a marcas de época. También agrego aquí el concepto de "cineplástica" acuñado por Elie Faure, término que alude tanto a la plasticidad del cine como a la posibilidad de reinventar la plástica gracias a las potencialidades de la cámara. ${ }^{45} \mathrm{~A}$ su vez, algunos postulados de Pascal Bonitzer en la relación del cine y la pintura pueden ser útiles. Tres elementos se destacan para el análisis: el cuadro (en el cine se le suma el movimiento y el tiempo); el plano-cuadro (una pausa en el movimiento del filme: se trata de aquellos instantes puramente plásticos de suspensión narrativa); el desencuadre (procedimiento eminentemente cinematográfico que genera una tensión no narrativa). ${ }^{6}$ Cabe señalar que todos estos conceptos que permiten relacionar el cine con la pintura en lo referente a las formas expresivas toman en este corpus nuevas dimensiones ya que estamos frente a cortometrajes en los cuales el contenido refiere también al ámbito de la plástica. Este metadiscurso es propio de la modernidad cinematográfica.

Los tres cortometrajes del corpus se realizaron en la etapa de gestación y consolidación de la modernidad cinematográfica en la región y fueron elaborados en contextos de producción disímiles. Spilimbergo (Jorge Macario, 1959)

43. Jordi Balló, Imágenes del silencio. Los motivos visuales en el cine (Barcelona: Anagrama, 2010), 17. 44. Ana Laura Lusnich, "Hacia una iconografía revolucionaria: los usos políticos y sociales de las imágenes en las representaciones de los procesos y conflictos revolucionarios de América Latina", en Actas III Congreso Internacional de la Asociación Argentina de Estudios de Cine y Audiovisual (Córdoba: Asociación Argentina de Estudios sobre Cine Audiovisual, 20I2), 5.

45. Elie Faure, La función social del cine (Buenos Aires: Ediciones Leviatán, 1956).

46. Pascal Bonitzer, Desencuadres. Cine y pintura (Buenos Aires: Santiago Arcos Editor, 2007). 
se gestó dentro del Taller de Cine con un préstamo del Fondo Nacional de las Artes, El retrato (Óscar Valdés y Humberto Solás, 1963) lo produjo el Instituto Cubano del Arte e Industria Cinematográficos (ICAIC) y La creación artística: Vicente Rojo (Juan José Gurrola, 1965) se concibió para la Coordinación de Difusión Cultural de la UNAM. Este último, como he mencionado, forma parte de una serie del mismo director sobre otros artistas plásticos destacados del momento. El hecho de haber seleccionado sólo esta pieza responde a la cualidad que Israel Rodríguez le adjudica: "es en la cinta dedicada a Vicente Rojo que el cineasta lleva a su máxima expresión la relación entre el cine y la plástica”. ${ }^{47}$ $\mathrm{Al}$ retomar, se trata entonces de un grupo de producción independiente junto con un subsidio de una institución estatal, un organismo industrial oficial y una entidad universitaria nacional. Como bien señalé, los tres ejemplos pertenecen a la corriente del filme sobre arte y su inserción dentro de las variantes anteriormente analizadas conducen inevitablemente al primer rango de contraste considerado: la hibridación de categorías fílmicas.

Spilimbergo versa sobre la obra plástica del artista homónimo, Lino Enea Spilimbergo, y el filme contiene únicamente imágenes fijas de los cuadros y grabados del autor junto con textos poéticos recitados esporádicamente por una voz en over. Al seguir las categorías teorizadas por Peydró, este corto estaría situado en la primera de ellas donde se produce una dramatización de las pinturas, construyéndose de este modo una narración audiovisual por medio del trabajo de la cámara, el encuadre y el montaje. Ahora bien, no se trata únicamente de una simple articulación de cuadros ya que, como anticipé y profundizaré luego, movimientos evidentes de cámara y la función de ésta como el ojo humano tendrán lugar en el filme. En este sentido, no se podría etiquetar a dicho filme breve como un documental de registro puesto que la experimentación en la estructura narrativa y visual del relato ocupa un espacio central. La presencia clara del montaje como recurso rector, la reflexión sobre el lenguaje cinematográfico y las relaciones visuales en unión con las asociaciones que proponen los textos líricos posibilitarían vincular el corto al campo fluctuante del ensayo audiovisual.

El retrato y La creación artística: Vicente Rojo comparten algunas de las tipologías aunque se diferencian claramente en otras. El primero se centra en torno a un pintor que, para alcanzar la inspiración, persigue a una mujer de carácter imaginario que registra en un cuadro hallado en una casa abandonada. En un

47. Israel Rodríguez, "El film sobre arte en México, 1960-1975”, en Cineplástica. El film sobre arte en México 1960-1975 (Ciudad de México: Museo de Arte Moderno, 2015), 28. 
juego de transposición de soportes, el corto está basado en el cuento homónimo del pintor y cuentista cubano Arístides Fernández Vázquez. En principio se filma el proceso creativo del artista que pinta sobre el lienzo, desarrollo de corte documental. No obstante, el pintor resulta de la construcción de un personaje ficcional al interior de una puesta en escena. Sin embargo, estaríamos frente a una resemantización de la sexta categoría de Peydró puesto que no asistimos a la biografía ficcionalizada del artista plástico sino a una transmediación creativa de los caracteres del cuento y su "artista". A su vez, la estructura del relato, sin diálogos y con un montaje marcado, ubicaría a este corto en la tendencia poética al poner en un plano visible las cualidades del lenguaje cinematográfico. En este caso se reelaboran los límites entre las tres categorías fílmicas. En el segundo ejemplo, centrado en la producción pictórica del artista español-mexicano Vicente Rojo, la conjunción de variantes y esquemas es también un punto a destacar. Gran parte del relato desarrolla el proceso creador del pintor cuya figura aparece en campo. Empero, la intervención de la realidad, la manipulación del material sensible (realizado por el propio artista en la fase de edición del filme) y la incorporación de insertos documentales acercan al filme breve a la tendencia poética de asociación visual y conceptual, y convierten al corto en un filme-ensayo. De esta forma, "el sentido pedagógico se ve suplantado por una búsqueda destinada a la convergencia de las disciplinas y a la extensión del medio como una alternativa política" ${ }^{48}$ Asimismo, y de forma experimental, el acercamiento hacia las obras plásticas de Rojo está presente, si bien se realiza de un modo diverso a Spilimbergo puesto que en este último dicho procedimiento vertebra el cortometraje y mantiene un valor capital.

El intercambio y la hibridación entre las categorías fílmicas, visible en los tres cortometrajes, remite a la experimentación en un nivel estructural del filme, por lo que no se trata de una renovación aislada en secuencias específicas sino que se sostiene en términos macroglobales. Ésta se sustenta, como ya pudo apreciarse, en la innovación y exploración de los recursos que ofrece el medio cinematográfico y las potencialidades que manifiesta su "gramática". En Spilimbergo la cámara y el montaje, procedimientos definitorios y distintivos del arte cinematográfico, le imprimen a las imágenes fijas (pinturas y grabados) movimiento, circulación y dinamismo. El corto se inicia con dibujos del artista intercalados entre los créditos. De inmediato irrumpe el travelling de acercamiento 
a las representaciones pictóricas. De este modo, la cámara realiza la función de la mirada humana que recorre completamente la pintura para luego focalizar, recortar el campo visual en planos cerrados de diferentes fragmentos del cuadro. En este sentido, movimientos horizontales, verticales, alejamientos y acercamientos se suceden una y otra vez otorgándole a la imagen bidimensional un sentido de espacialidad cinematográfica. Esta forma expresiva ilumina el concepto de "cineplástica", ya que ambas disciplinas se retroalimentan. El cine, en estos movimientos de cámara, en los encuadres cerrados sobre segmentos de la pintura y los respectivos desencuadres a las figuras, refuerza sus componentes plásticos. Al mismo tiempo la plástica es revisitada por la cámara de un modo singular y se nutre de los primeros planos, de la ampliación del cuadro y de la movilidad de los elementos contenidos en éste. Por momentos la armonía y el ritmo pausado se quiebran mediante un movimiento brusco de cámara acompañado generalmente por una modificación en la banda sonora, en correspondencia con el motivo del cuadro que se explora en ese preciso instante. Por otra parte, en torno a ciertas pinturas en las que se retratan personas, la cámara y el montaje construyen un efecto narrativo más claro aún que en los casos anteriores. Por ejemplo, después de unir por corte directo a dos personajes que en el cuadro se encuentran distanciados, la cámara, a partir de un primerísimo plano del rostro, se acerca con la intención de introducirse en el ojo de la figura moldeada. Este recurso resulta completamente innovador. Al promediar el cortometraje hace su aparición una voz en over poemática y expresiva que le agrega mayor sensibilidad a las imágenes. ${ }^{49}$ Luego también se exhiben grabados en blanco y negro, y éstos se presentan asimismo mediante formas experimentales que evidencian la renovación moderna del lenguaje: a través de movimientos giratorios de cámara; detrás de una especie de telón teatral donde un velo negro cubre y descubre las obras; a partir de un mecanismo similar al del pasaje de diapositivas, como si éstos fuesen fotogramas de una película que muestra su propio acontecer espacial. Finalmente, el cortometraje concluye con una representación plástica de Lino Enea Spilimbergo en pleno proceso creativo y apuntando su mirada hacia la posición de la cámara; gesto autorreflexivo que equipara al pintor como hacedor de los cuadros con el director como creador de las imágenes audiovisuales.

49. Frases como "la muerte buscaba salir a la luz, se asomaba por los ojos, navegaba por las venas, iba aflorando rápidamente" colaboran junto con los recursos fílmicos a narrativizar los cuadros plásticos. 
En El retrato los diferentes planos de realidad dentro de la ficción están articulados de forma experimental mediante motivos puramente plásticos. Si bien los personajes y la trama narrativa son ficcionales, las imágenes iniciales podrían referir al estilo documental, al rescatar el proceso creativo del artista: un lienzo vacío ocupa la totalidad del cuadro fílmico y un brazo comienza a dar las primeras pinceladas. Acto seguido, en busca de inspiración, el artista posa su mirada en el mar para luego perderse en el interior de su ser. En ese instante, como si nos trasladáramos a un plano mental, presenciamos una sobreimpresión de la pintura y el mar a partir de cuatro orientaciones diversas unidas por el recurso del desenfoque. Esta figura, rupturista e innovadora en términos formales, remite directamente al concepto de "plano-cuadro" de Bonitzer, puesto que se trata de un momento esencialmente plástico que pone entre paréntesis el desarrollo narrativo del filme. Luego, la estética documental parecería retornar con primeros planos de las herramientas del quehacer artístico hasta que el personaje, disconforme, arruina el cuadro. Ahora sí, el siguiente motivo plástico de articulación deriva completamente a otro plano de realidad: la cámara se introduce en un bastidor nuevo y por montaje ésta sale del lienzo para trasladarnos a otro ambiente, un bosque, en el cual el artista, pensativo, busca inspiración. De nuevo se exhibe un tratamiento moderno de los recursos cinematográficos. Esta escena, de iluminación exigua, cuasi fantástica, se erige por un lado como un cuadro plástico, perfectamente delimitado, y por el otro representa un motivo visual o motivo emergente que, con variaciones, se encuentra en otros filmes de la corriente sobre arte: el artista solitario, meditabundo y reflexivo. Allí, en este plano imaginativo surge una muchacha a la cual el artista decide perseguir. A partir de entonces la diferenciación de planos de realidad se torna aún más confusa, así como la causalidad y temporalidad de las acciones. El artista vuelve a pintar sobre el lienzo esta vez un retrato de la mujer; mujer con la cual no tiene contacto y cuya imagen encuentra, en el final del corto, dentro de una casa abandonada en una pintura colgada en la pared. La última secuencia del relato también denota un tinte fantástico. El artista entra a la casa casi a oscuras y por medio de una toma subjetiva transita la misma hasta que finalmente la cámara se enfrenta con la pintura mencionada y, de forma similar a Spilimbergo, la recorre hasta que concluye el filme. La brevedad del metraje permite en suma conformar un relato híbrido, ausente de diálogos y sin la necesidad de profundizar en la construcción psicológica de personajes mostrados como seres performáticos, que entrelaza aspectos narrativos con otros de carácter plástico. 
A diferencia del filme cubano, La creación artística: Vicente Rojo parte de la concepción documental para introducir momentos performáticos que rozan la ficción y explora las posibilidades del dispositivo fílmico por medio de la inserción de procedimientos propios del cine experimental más puro. Resulta interesante en este filme la conformación del tándem narratividad/plasticidad, ya que el seguimiento del proceso creativo de Vicente Rojo, a partir del registro del acto creativo y la exhibición de sus obras, se conjuga con la intervención de la realidad por parte del artista. De este modo se cimienta una nueva obra artística de carácter plástico-cinemática. El corto comienza con una niña que proyecta las ondulaciones de un cuadro fuera del mismo a lo largo de una pared, acción que se reiterará al promediar el filme. Luego de este primer acercamiento (atípico) a la obra de Vicente Rojo una cámara baja nos introduce en el taller del pintor donde éste se dispone a la creación mientras la voz en over explica los detalles de los preparativos. Acto seguido, a partir de la técnica del stop motion, cuatro bastidores en el suelo comienzan a completarse y transformarse en obras plásticas como si de un acto mágico se tratara, proceso que se prolonga por unos minutos y que explicita un claro gesto renovador. La secuencia siguiente dará rienda suelta a la manipulación directa del material sensible, iluminando uno de los postulados presentados por la voz narradora: "la pintura hace visible y nos abre las puertas de una nueva realidad”. La cámara acompańa a Vicente Rojo en el interior del automóvil que maneja y a través del parabrisas, como el marco de un cuadro pictórico, la realidad exterior se transforma en material plástico. En principio se incorpora un filtro con ondulaciones a la imagen y luego se suceden innumerables figuras geométricas y abstractas intervenidas, mediante ralladuras y solarizaciones, sobre objetos de la realidad exterior: automóviles, bicicletas, puentes, entre otros. Esta gran secuencia central, que manifiesta la reflexión sobre el lenguaje propio de la modernidad, se intercala con un montaje de los cuadros reales del artista desde una perspectiva similar a la encontrada en Spilimbergo y con el performance de la niña que esta vez copia el motivo de los cuadros en la pared de la calle. Posteriormente un collage visual sobre los orígenes de Rojo en España, mediante un montaje rápido y el movimiento evidente de cámara, ocupa la totalidad del cuadro fílmico articulando dibujos, fotografías documentales y pinturas. Finalmente, la última escena del corto recupera ese motivo emergente que se encuentra en El retrato en torno al artista pensativo que busca inspiración y el lienzo vacío que se cubre de contenido plástico. Estas imágenes refuerzan la premisa de que la participación de Rojo en el filme es de orden performática (en el borde 
entre la ficción, el documental y lo experimental) y no de índole testimonialbiográfica tradicional.

En última instancia se aborda el tercer rango de contraste en relación al campo semántico de estos cortometrajes y su vinculación con la renovación del campo cultural y artístico en cada contexto de producción. En algunos ejemplos el contenido referencial remite directamente a las innovaciones que se estaban produciendo en el terreno del arte en el momento de elaboración del filme; en otros, la alusión es indirecta pero no por ello menos significativa. Éste es el caso de Spilimbergo. Si bien Lino Enea Spilimbergo estaba vivo cuando se realizó el cortometraje, ${ }^{50}$ su producción artística remite a un periodo anterior. No obstante, su deseo de modernización del arte argentino en los años veinte (renovación del lenguaje, de la enseñanza y de las formas de circulación del arte) estaba en sintonía con los postulados que afloraron en el campo cultural argentino de los años cincuenta/sesenta. Como muchos de los nuevos artistas de la época, Spilimbergo tenía un contacto fluido con las tendencias europeas. Tal es así que hacia finales de los años veinte conformó, junto con otros artistas argentinos entre los que se encontraban Antonio Berni y Héctor Basaldúa, el Grupo de París en un intento de traer al país las experiencias innovadoras del Viejo Continente. Más allá de su impronta cubista, el rescate de su obra a comienzos de la década de los sesenta se orienta no tanto a valorizar la técnica o el estilo configurado sino a ponderar a un artista local que ha intentado modernizar el campo artístico en un sentido global. La reconfiguración artística de la época tomó otros rumbos estilísticos, pero el espíritu renovador fue semejante.

Es posible hallar una situación similar en El retrato. Como bien se ha analizado, Cuba experimentó una marcada transformación cultural y artística a partir de la revolución, y entonces el rescate de lo nacional era una prioridad. En este sentido, el pintor y cuentista local Arístides Fernández Vázquez (I904-I934) resulta singular. El cortometraje reconstruye (y homenajea) de forma audiovisual y poética el cuento homónimo de uno de los máximos exponentes de la vanguardia y la primera modernidad de Cuba. No sólo es pertinente su revalorización en tiempos de renovación por su estilo formal, profundamente expresionista, sino por el componente social de su pintura. En ella se refleja, con gran sensibilidad emotiva, la agitada realidad de la dictadura de Gerardo Machado. Innovación y compromiso social son dos aristas que la Cuba revolucionaria quiso

50. Éste murió al poco tiempo, en 1964, el mismo año el Fondo Nacional de las Artes le rindió un homenaje. 
remarcar. En este sentido, ciertos valores del pasado eran rescatados dentro de este nuevo proceso. Todas las exposiciones de sus obras fueron realizadas después de su muerte, muchas de ellas en los años cincuenta y sesenta. Y así como fue un precursor en el ámbito de la pintura también es considerado un antecedente del cuento fantástico, en literatura. De forma análoga a su estética pictórica, el expresionismo, sus cuentos versan en torno a desequilibrios mentales y desarrollos del inconsciente, como en el ejemplo analizado. En resumen, en $E l$ retrato se articulan de forma innovadora componentes renovadores de la pintura, el cine y la literatura tanto en el aspecto expresivo como en el campo de sentido, colaborando con los objetivos culturales del proceso revolucionario.

Distinto es el panorama alrededor del corto mexicano La creación artística: Vicente Rojo. Ahí la correlación con el contexto cultural es inmediata. Vicente Rojo, representante de la Generación de la Ruptura, era un personaje activo en el instante de gestación del filme. Y como se pudo observar, la ruptura formal en sus obras fue trasladada por el cineasta a la estructura narrativa y estética del cortometraje. Según Juan García Ponce, crítico de arte mexicano y defensor de dicho movimiento, la obra de Rojo se caracteriza por embestir la noción tradicional de "obra", desentenderse de la idea de la imagen bella, y la autorreferencia, entre otras cualidades. ${ }^{5 \mathrm{I}}$ Sus pinturas son eminentemente abstractas en donde se destacan las figuras geométricas. El hermetismo que genera la abstracción y la simplificación de los elementos contenidos en el cuadro están conectados con el espíritu autorreflexivo de la modernidad. Este rasgo puede observarse no sólo en la técnica y el estilo de sus pinturas sino también en el modo de concebir su obra personal, puesto que en gran parte de su vida ha recurrido al trabajo en serie donde la interrelación con y la referencia a las obras previas es el núcleo central de la propuesta. En definitiva, el cortometraje reflexiona sobre la doble renovación cultural simultánea, cinematográfica y plástica, "tematizando" la ruptura pictórica a partir de la conjunción de elementos plásticos y fílmicos "rupturistas".

De este modo, los tres filmes ponen en escena artistas cuyas obras, de una u otra manera, funcionan como un valor de sustento y refuerzo de la modernización del campo cultural y artístico local/regional. Ahora bien, el carácter moderno de los cortos no reside únicamente en la simple alusión al arte innovador sino que radica, por sobre todas las cosas y de acuerdo a lo analizado, en la experimentación de las formas de expresión.

5I. Juan García Ponce, Nueve pintores mexicanos (Ciudad de México: DGE Ediciones, 1968). 


\section{Conclusiones}

A lo largo del presente trabajo he procurado desentrañar el papel desempeñado por el cortometraje en Latinoamérica durante los ańos cincuenta y sesenta. A partir de la selección de tres cinematografías heterogéneas en cuanto a la conformación de sus tradiciones institucionales-industriales (Argentina, México y Cuba), el estudio de los respectivos contextos culturales y artísticos dentro del periodo consignado, y el análisis textual de un corpus de cortos pertenecientes a la corriente del filme sobre arte he podido corroborar las hipótesis planteadas. Efectivamente el cortometraje, tanto en países con industrias fílmicas consolidadas como en aquellos que manifestaron una producción esporádica o intermitente, tuvo un papel central en el impulso inicial y posterior desarrollo de la modernidad cinematográfica. El filme breve, gracias a sus cualidades potenciales como la libertad estética que deriva de la ausencia de condicionamientos comerciales, la brevedad y condensación de los tiempos, y la relación inmediata que se establece con el receptor llevó adelante una renovación expresiva y semántica. Tres son los rasgos modernos que se examinaron de forma transversal en Spilimbergo (Jorge Macario, 1959), de Argentina; El retrato (Óscar Valdés y Humberto Solás, 1963), de Cuba; y La creación artística: Vicente Rojo (Juan José Gurrola, 1965), de México: la hibridación de categorías fílmicas, la experimentación con los recursos cinematográficos y la construcción de sentido en diálogo con las innovaciones acaecidas en el terreno cultural y artístico local/ regional. Si bien se encontraron algunas diferencias en cuanto a los medios de financiación de las películas (oficiales, estatales, independientes), con relación a los modos de aproximación a los movimientos artísticos y a la concepción narrativa y plástica del filme, los tres ejemplos evidenciaron un deseo compartido por renovar las formas expresivas y acompañar las transformaciones generales en el ámbito sociocultural y estético.

En suma, esta investigación resulta un aporte sustancial para los estudios sobre cine en América Latina. La originalidad de la propuesta reside en la novedad del objeto de estudio y en el carácter metodológico de abordaje: el examen comparado del cortometraje latinoamericano en tanto pilar fundamental de la modernidad cinematográfica. A partir de este enfoque obtenemos una perspectiva más profunda, completa y articulada de los componentes innovadores del cine moderno en el territorio. No obstante, este trabajo puede - $y$ debe- expandirse mediante la incorporación de otras cinematografías como por ejemplo de Chile o Brasil que revelaron realidades culturales y fílmicas 
disímiles, con el objetivo de afianzar aún más la premisa del cortometraje como un medio de renovación expresivo-semántica. Asimismo, se desprenden de este trabajo otras líneas de estudio pertinentes para el campo académico. Entre ellas se puede señalar el análisis de la reconfiguración del entramado cinematográfico latinoamericano a partir de finales de los años sesenta y la labor fundamental del cortometraje que, continuando con la exploración estética del dispositivo, se erigió en tanto vehículo de instrumentación y accionar político directamente vinculado con la efervescencia social y la represión institucional que vivía la región. \$ 